\title{
BASIC NUTRITIONAL PROPERTIES OF CORNELIAN CHERRY (CORNUS MAS L.) CULTIVARS GROWN IN THE CZECH REPUBLIC
}

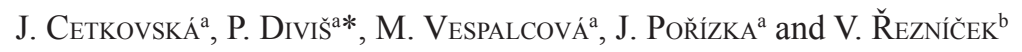 \\ ${ }^{a}$ Brno University of Technology, Faculty of Chemistry, Institute of Food Science and Biotechnology, \\ Purkyňova 118, Brno. Czech Republic \\ ${ }^{\mathrm{b}}$ Mendel University in Brno, Faculty of Horticulture, Department of Breeding and Propagation of Horticultural \\ Plants, Valtická 337, Lednice. Czech Republic
}

(Received: 30 April 2013; accepted: 25 June 2013)

The ascorbic acid, total polyphenols, total anthocyanins and mineral content, together with antioxidant activity, was determined in five Czech, two Ukrainian and two Austrian cultivars of cornelian cherry (Cornus mas L.) widely grown in the Czech Republic. Ascorbic acid content varied between 199-433 mg kg-1, total polyphenols between 2174-6143 $\mathrm{mg} \mathrm{kg}^{-1}$, and total anthocyanins between $61-253 \mathrm{mg} \mathrm{kg}^{-1}$. All fruits were good sources of major metals $(\mathrm{K}, \mathrm{Ca}, \mathrm{Mg}, \mathrm{Fe}$, and $\mathrm{Mn}$ ) and trace elements $(\mathrm{Cu}, \mathrm{Zn}$, and $\mathrm{Cr})$. The antioxidant activity was determined by EPR and DPPH radical scavenging assay and ranged from $29.5 \%$ to $67.2 \%$. There was a linear relationship between antioxidant activity and total polyphenol content. Based on the obtained results, Ekotišnovský, Fruchtal, and Ruzyňský cultivars were recommended for further investigation and breeding programme of cornelian cherry fruit in the Czech Republic.

Keywords: cornelian cherry, antioxidant activity, mineral elements, ascorbic acid, polyphenols

The significance of less common fruit trees is not negligible. Most of them have modest demands for growing conditions and grow well in extreme habitats. They can be harvested every year, and their fruit have a high biological value with beneficial effects on human health.

Cornelian cherry (Cornus mas, L.) is $2-8 \mathrm{~m}$ high shrub cultivated mainly in Central and Southern Europe, in Asia Minor, and in the Caucasus. The fruit of cornelian cherry are twoseeded, red coloured, oval shaped, 10-30 mm long drupes with a weight of 2-5 g, containing many nutritive substances (Karadeniz et al., 2002; Demir \& Kalyoncu, 2003; Paprštein et al., 2009). They are suitable for direct consumption, however, they are mostly processed into various products, such as jams, jellies, marmalades, stewed fruit, yogurts, juice, syrups, and liquors.

In earlier times cornelian cherry was widely cultivated in southern regions of the Czech Republic, nowadays it is nearly forgotten, although it still wildly grows in this locality. One of the reasons is the fact that cornelian cherry is still not mentioned in the Czech National List of Varieties and thus it is out of interest for the farmers.

The aim of this work was to determine five nutritional parameters in nine cornelian cherry cultivars that predominantly grow in the Czech Republic, to compare each variety on the basis of the obtained results, and to select the best cultivar for a breeding programme of cornelian cherry fruit in the Czech Republic.

\footnotetext{
* To whom correspondence should be addressed. Phone: +420-54114-9454; fax: +420-541211697; e-mail: divis@fch.vutbr.cz
} 


\section{Materials and methods}

\subsection{Samples}

Fruit were harvested within the period of 2009-2010 in the experimental orchards of Brno Mendel University in Žabčice (approx. $20 \mathrm{~km}$ south of Brno city, Czech Republic). Average altitude of this locality is 185 metres, mean precipitations oscillate in from 450 to $550 \mathrm{~mm}$ per year and average year temperature reaches $9.3{ }^{\circ} \mathrm{C}$. The soil type in the orchard was classified as sandy-clay alluvial soil consisting mostly of marginal weathered material rich in organic compounds. Samples were stored under $-18^{\circ} \mathrm{C}$ prior analysis and analysed as soon as possible. The samples represented nine varieties of cornelian cherry: Ekotišnovský, Olomoucký, Ruzyňský, Sokolnický, Tišnovský (Czech cultivars), Fruchtal, Joliko (Austrian cultivars), and Lukjanovskij and Vydubeckij (Ukrainian cultivars). Before the analysis, thirty randomly chosen fruits were mixed together and used for the analyses. From the selected fruit purée was made using a mixer and the final average sample was obtained by dividing into quarters.

\subsection{Chemical analysis}

Ascorbic acid was determined after homogenization of 5-6 g of cornelian cherry sample with $2 \%$ metaphosphoric acid. Homogenized samples were filtered through $0.45 \mu$ m nylon filter before the analysis on High Performance Liquid Chromatograph (Waters 1515, Waters Corporation, USA). The L-ascorbic acid standard was used to calibrate the chromatograph. Total amount of $20 \mu$ filtered solution was injected on Gemini Reversed Phase C18 column $(150 \times 4.6 \mathrm{~mm} ; 5 \mu \mathrm{m}$; Phenomenex) with Security Guard Cartridges (Gemini C18 $4 \times 3 \mathrm{~mm}$, Phenomenex). Mobile phase consisted of $0.1 \mathrm{M} \mathrm{KH}_{2} \mathrm{PO}_{4}$ and contained $10 \%(\mathrm{v} / \mathrm{v})$ of methanol. The isocratic flow of mobile phase was set to $1 \mathrm{ml} \mathrm{min}^{-1}$. Analysis was performed at $30{ }^{\circ} \mathrm{C}$ and the analyte was detected using UV-VIS detector (Waters 2487, Waters Corporation, USA) at $254 \mathrm{~nm}$.

The extract for total polyphenols and anthocyanins analysis was prepared from $20 \mathrm{~g}$ of fruit purée and $100 \mathrm{ml}$ of ultrapure water acidified by $0.1 \mathrm{M} \mathrm{HCl}$. After thorough mixing, the mixture was centrifuged at 6000 r.p.m. for $10 \mathrm{~min}$ and filtered. Total polyphenols were determined by UV-VIS spectrophotometer (Helios Gamma, Thermo Fisher Scientific) using Folin-Ciocalteu reagent (Popovic et al., 2012). Gallic acid was used as standard.

Total anthocyanins were measured at 510 and $700 \mathrm{~nm}$ in two buffers at $\mathrm{pH} 1.0$ and 4.5 using pH-differential spectrophotometric method (Popovic et al., 2012).

Antioxidant activity was performed using electron paramagnetic resonance spectrometer (Miniscope MS 300, MagnetTech, Germany) and DPPH (2,2-diphenyl-1-picrylhydrazyl) radical scavenging assay (PoLOvKA, 2006). Each sample extract was diluted 50 times prior the addition of 'DPPH solution (concentration $\mathrm{c}_{\mathrm{DPPH}}$ in ethanol $=0.63 \mathrm{mmol} \mathrm{l}^{-1}$ ). Antioxidant activity of the sample was quantified by comparison of 'DPPH relative concentration after 14 minutes from mixing the $\mathrm{DPPH}$ solution with the sample. The antioxidant activity was expressed as a decrease of relative ${ }^{\circ} \mathrm{DPPH}$ concentration.

The mineral content was determined after wet-ashing of $500 \mathrm{mg}$ dry weight fruit sample in a microwave oven (Milestone1200, Bergamo, Italy) using $6 \mathrm{ml}$ of a mixture (2:1) of nitric acid and hydrogen peroxide and a defined time performance program. Analysis of all samples was performed on Q-ICP-MS (X-series, Thermo Scientific) with the following conditions: plasma gas flow $131 \mathrm{~min}^{-1}$, auxiliary gas flow $0.71 \mathrm{~min}^{-1}$, nebuliser gas flow $0.91 \mathrm{~min}^{-1}$, 
forward power $1300 \mathrm{~W}$. Collision cell containing Ar-He gas mixture $\left(5 \mathrm{ml} \mathrm{min}{ }^{-1}\right)$ was used during the measurement to reduce the spectral interferences. The instrument was calibrated using multielemental standard solution prepared by mixing standards of individual elements of interest.

\subsection{Statistical analysis}

The data obtained were analysed statistically in Statistica 10.0 software (Stat Soft, Inc.) and the results were displayed in mean values with standard deviation $(n=3)$. Significance of the differences among the numbers was determined by Duncans multiple range test at $\mathrm{P}<0.05$ significance level.

\section{Results and discussion}

The results from analyses of selected cultivars are given in Tables 1 and 3 .

The highest content of ascorbic acid (vitamin C) was measured in Ekotišnovský cultivar (433 mg kg-1), while the lowest in Vydubeckij cultivar $\left(198 \mathrm{mg} \mathrm{kg}^{-1}\right)$. These results are in accordance with the results obtained by the Research and Breeding Institute of Pomology Holovousy Ltd. (Czech Republic) during the years 2004-2006 (PAPRŠTEJN et al., 2009). On the other hand, Rop and co-workers (2010) measured almost 10 times higher ascorbic acid content in 12 different cornelian cherry cultivars (6 of them were the same as in this study) harvested in the experimental orchard of Tomas Bata University Zlin (Czech Republic) within the period of 2007-2009. For the comparison, the contents of ascorbic acid in cornelian cherries grown in other parts of Europe and Asia are shown in Table 2. As can be seen the ascorbic acid content in the studied cultivars can be compared with other cultivars grown in the other part of world, however, some cornelian cherries, mainly from Azerbaijan, Greece, and Turkey, can be richer in ascorbic acid compared to our studied cultivars. In the average, consumption of $100 \mathrm{mg}$ of investigated fruit cultivars can cover about $30 \%$ of recommended dietary allowance of vitamin C for woman and men (DRISKELL, 2009).

Table 1. Total anthocyanins $\left(c_{\mathrm{ACY}}\right)$, ascorbic acid $\left(c_{\mathrm{AA}}\right)$, total polyphenols $\left(c_{\mathrm{TP}}\right)$ content and antioxidant activity (AOA) of cornelian cherry cultivars

\begin{tabular}{|c|c|c|c|c|}
\hline Cultivar & $c_{\mathrm{ACY}}, \mathrm{mg} \mathrm{kg}^{-1}$ & $c_{\mathrm{AA}}, \mathrm{mg} \mathrm{kg}^{-1}$ & $c_{\mathrm{TP}}, \mathrm{mg} \mathrm{kg}^{-1}$ & $\mathrm{AOA}, \%$ \\
\hline Ekotišnovský & $220 \pm 3^{e}$ & $433 \pm 36^{\mathrm{d}}$ & $6143 \pm 195^{\mathrm{g}}$ & $67.25 \pm 1.25^{\mathrm{e}}$ \\
\hline Fruchtal & $194 \pm 5^{d}$ & $365 \pm 24^{c}$ & $4117 \pm 84^{\mathrm{e}}$ & $60.95 \pm 0.15^{\mathrm{d}}$ \\
\hline Joliko & $61 \pm 7^{\mathrm{a}}$ & $233 \pm 14^{\mathrm{ab}}$ & $2174 \pm 77^{b}$ & $37.3 \pm 3.5^{\mathrm{b}}$ \\
\hline Lukjanovskij & $347 \pm 4^{g}$ & $214 \pm 43^{\mathrm{ab}}$ & $1823 \pm 10^{\mathrm{a}}$ & $37.3 \pm 0.6^{b}$ \\
\hline Olomoucký & $160 \pm 6^{c}$ & $335 \pm 30^{c}$ & $2438 \pm 35^{\text {bc }}$ & $29.55 \pm 1.75^{\mathrm{a}}$ \\
\hline Ruzyňský & $253.8 \pm 2.9^{\mathrm{f}}$ & $348 \pm 12^{\mathrm{c}}$ & $4259 \pm 131^{\mathrm{e}}$ & $52.0 \pm 3.6^{\mathrm{c}}$ \\
\hline Sokolnický & $99.2 \pm 0.4^{\mathrm{b}}$ & $390 \pm 18^{\mathrm{cd}}$ & $3621 \pm 9^{\mathrm{d}}$ & $41.61 \pm 1.20^{\mathrm{b}}$ \\
\hline Tišnovský & $153.4 \pm 1.3^{\mathrm{c}}$ & $249 \pm 19^{b}$ & $2683 \pm 13^{c}$ & $41.4 \pm 0.7^{\mathrm{b}}$ \\
\hline Vydubeckij & $109.8 \pm 0.8^{\mathrm{b}}$ & $199 \pm 17^{\mathrm{a}}$ & $4782 \pm 172^{\mathrm{f}}$ & $51.6 \pm 1.6^{\mathrm{c}}$ \\
\hline
\end{tabular}

Values in the same column with different letters are significantly different at $\mathrm{P}<0.05$ 
Table 2. Comparison of ascorbic acid content in different cornelian cherry cultivars grown around the world

\begin{tabular}{|c|c|c|c|}
\hline Cultivar & Location & $\begin{array}{l}\text { Ascorbic acid, } \\
\mathrm{mg} \mathrm{kg}^{-1}\end{array}$ & Reference \\
\hline $\begin{array}{l}\text { Ekotišnovský, Olomoucký, } \\
\text { Ruzyňský, Sokolnický, } \\
\text { Tišnovský, Fruchtal, Joliko } \\
\text { Lukjanovskij, Vydubeckij }\end{array}$ & Czech Republic, South Moravia & $199-433$ & This study \\
\hline n.a. & $\begin{array}{l}\text { Alborz Mountain Chain, Guilan, } \\
\text { North Iran }\end{array}$ & 446 & HASHEMPOUR et al., 2010 \\
\hline $\mathrm{C} 14, \mathrm{C} 15, \mathrm{C} 24, \mathrm{C} 25, \mathrm{C} 26, \mathrm{C} 27$ & Arasbaran, East Azerbaijan & $1655-2995$ & HASSANPOUR et al., 2011 \\
\hline $\begin{array}{l}01,02,03,05,06,07,08,09,10 \\
12,15\end{array}$ & Çoruh valley, Turkey & $437-767$ & GÜLERYÜZ et al., 1998 \\
\hline n.a. & Konya region, Turkey & 730 & KALYONCU et al., 2009 \\
\hline n.a. & Samsun, Turkey & $160-888$ & Tural \& Koca, 2008 \\
\hline $\begin{array}{l}14-09,44-01,44-05,44-16, \\
44-18,44-20,44-24,44-26, \\
67-01,77-04,77-05,77-06, \\
77-09,77-10,78-03,78-05\end{array}$ & $\begin{array}{l}\text { Western Black Sea and Inner } \\
\text { Anatolia regions, Turkey }\end{array}$ & $290-1120$ & YiLMAZ et al., 2009 \\
\hline n.a. & North-eastern Anatolia, Turkey & 372 & ASLANTAs et al., 2007 \\
\hline $\begin{array}{l}\text { CPC16, KC1, KC2, Bačka, } \\
\text { R1,PPC1, KDC1, KDC3, KKC1 }\end{array}$ & Serbia & $149-388$ & BIJELIC et al., 2011 \\
\hline 260 different genotypes & Gemer region, Slovakia & $164-385$ & BRINDZA et al., 2009 \\
\hline n.a. & Georgia & $505-1280$ & MAGHRADZE et al., 2009 \\
\hline $\begin{array}{l}\text { Bolestraszycki, Dublany, } \\
\text { Florianka, Juliusz, Kresowiak, } \\
\text { Paczoski, Podolski, Raciborski, } \\
\text { Słowianin, Szafer }\end{array}$ & Poland & $342-750$ & KUCHARSKA et al., 2011 \\
\hline Vermio & Veria, Northern Greece & 1633 & PANTELIDIS et al., 2007 \\
\hline
\end{tabular}

n.a.: not available

Total polyphenol content was the highest in Ekotišnovský cultivar $\left(6143 \mathrm{mg} \mathrm{kg}^{-1}\right)$ and the lowest in Lukjanovskij cultivar $\left(1823 \mathrm{mg} \mathrm{kg}^{-1}\right)$. The obtained results were within the limits of the values published by several authors for cornelian cherries from Czech Republic, Poland, Turkey, or Iran (Tural \& Koca, 2008; Yilmaz et al., 2009, Hashempour et al., 2010, Rop et al., 2010; KuCHARSKa et al., 2011), but were lower than the values reported by PANTELidis and co-workers (2007) in Vermio cultivar from Greece (15 $\left.920 \mathrm{mg} \mathrm{kg}^{-1}\right)$. The differences in total polyphenol content may be caused by the different extraction method used in that study compared to the other studies. It is well known that water extracts may have a lower extraction yield compared to application of organic solvents (KRATCHANOva et al., 2010), however, in food industry the cornelian cherry products are processed without support of organic compounds and thus water extraction can provide useful information in relation to the absorption of these substances by the human metabolism. The total polyphenol content correlated well with the antioxidant activity (Fig. 1., $\mathrm{R}^{2}=0.7985$ ), which confirms the hypothesis that consumption of cornelian cherry can strengthen the immune system and generally may have positive effect on human health. 


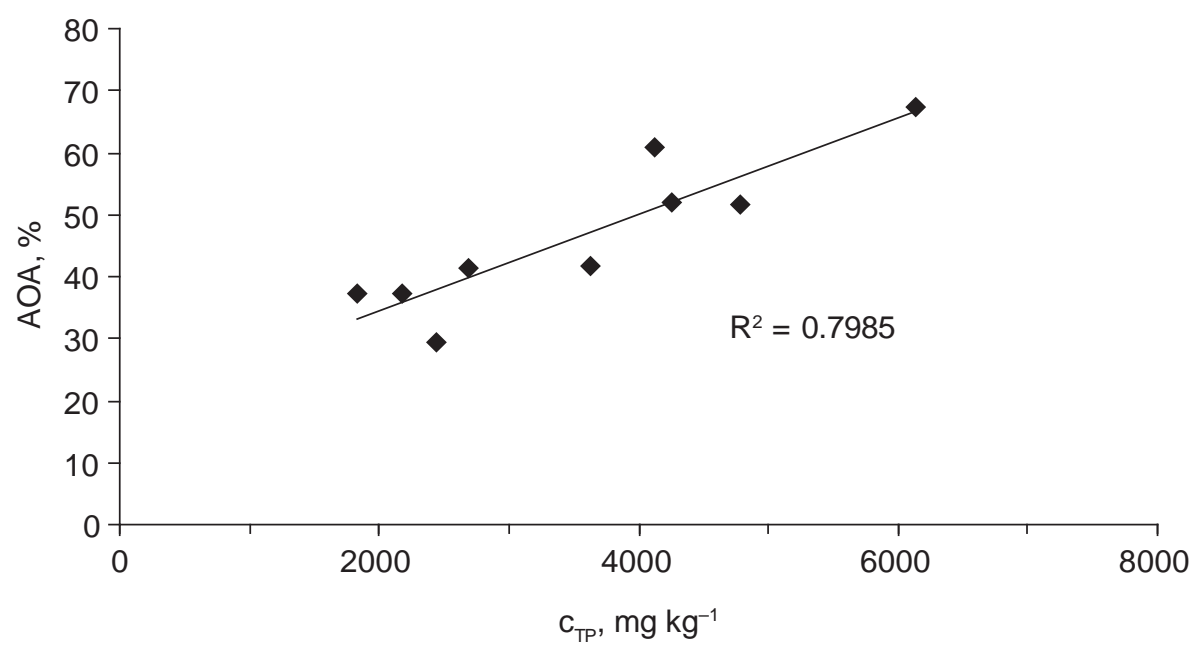

Fig. 1. Correlation between total polyphenols content $\left(\mathrm{c}_{\mathrm{TP}}\right)$ and DPPH radical activity (AOA)

The content of total anthocyanins ranged from $61 \mathrm{mg} \mathrm{kg}^{-1}$ (Joliko cultivar) to $347 \mathrm{mg} \mathrm{kg}^{-1}$ (Lukjanovskij cultivar). These results are in agreement with the results published by SEERAM and co-workers (2002) and BIJELIC and co-workers (2011) who analysed cornelian cherries from Serbia and the USA. Significantly higher anthocyanin concentrations (1068-4421 mg $\mathrm{kg}^{-1}$ ) were measured in cornelian cherries from Turkey, Iran (Tural \& KoCA, 2008; YILMAZ et al., 2009; Hassanpour et al., 2011), and Greece (PANTELIDis et al., 2007).

The highest antioxidant activity was observed in Ekotišnovský cultivar (67.2\%), while the lowest in Olomoucký cultivar (29.5\%). In other similar studies the antioxidant activity ranged from 31\% to $94.3 \%$ (YILMAZ et al., 2009; HASSANPOUR et al., 2011), although it was determined by different analytical methods.

The dominating mineral element in cornelian cherry cultivars was potassium. The potassium concentration varied between $4425 \mathrm{mg} \mathrm{kg}^{-1}$ and $9729 \mathrm{mg} \mathrm{kg}^{-1}$. Other important major elements related to human health are calcium, magnesium, iron, and manganese. In the average, the analysed cornelian cherry cultivars contained $931 \mathrm{mg} \mathrm{kg}^{-1} \mathrm{Ca}$ and $277 \mathrm{mg} \mathrm{kg}^{-1}$ $\mathrm{Mg}$. The iron and manganese contents were about $1 \mathrm{mg} \mathrm{kg}^{-1}$. The results of elemental analysis showed that all cornelian cherry cultivars are rich in essential metals $\left(0.40-4.48 \mathrm{mg} \mathrm{kg}^{-1}\right)$ except for chromium that was present in trace amount $\left(0.023-0.23 \mathrm{mg} \mathrm{kg}^{-1}\right)$. There are relatively few studies dealing with the mineral content of cornelian cherry. KALYONCU and co-workers (2009) reported significantly higher concentrations of major elements compared to this study. Nevertheless it can be said that the measured results are in agreement with the published data (Aslantas et al., 2007; BiJelic et al., 2011). All measured major and minor metal concentrations are below the tolerable upper intake levels and it can be concluded that, in the average, consumption of $100 \mathrm{mg}$ cornelian cherry fruit cover about $6-25 \%$ of the recommended dietary allowance of potassium, calcium, iron, manganese, copper, zinc, and chromium for woman and men (DRISKELL, 2009). 


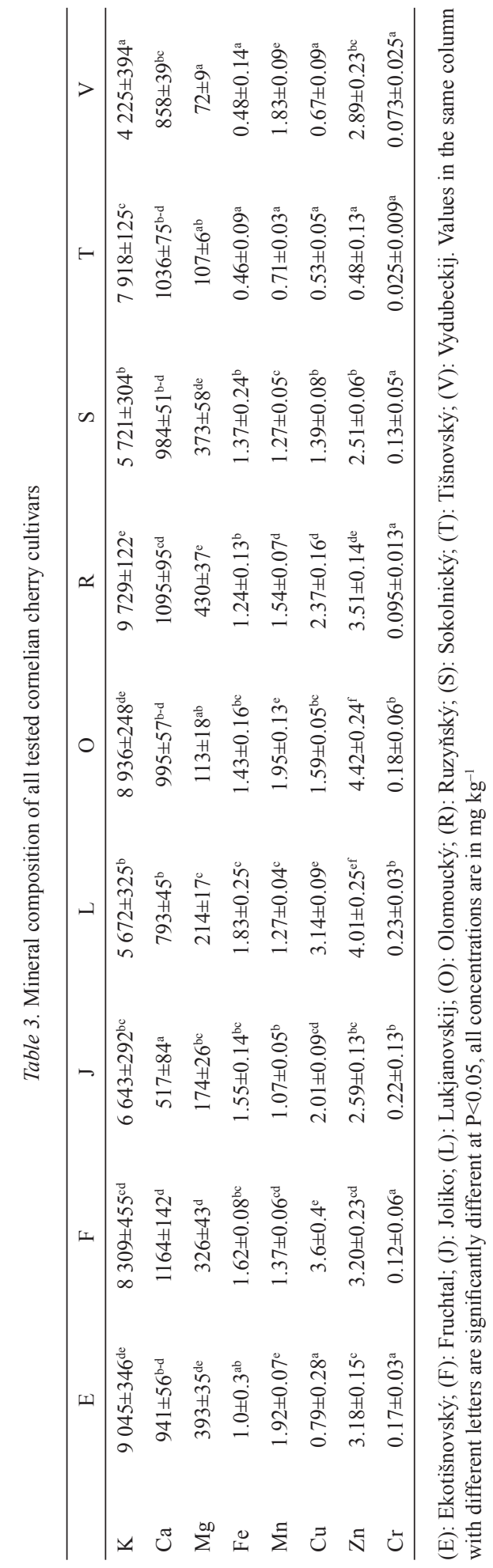




\section{Conclusions}

This study showed that Czech cultivars of cornelian cherry are comparable with the cornelian cherry cultivars grown around Europe and Western Asia in terms of ascorbic acid, polyphenols, anthocyanins, and mineral contents and antioxidant activity. The minor differences in the content of the studied compounds can be caused by several factors, soil type, geographical and environmental conditions, degree of fruit ripeness, manipulation during fruit processing, and selection of analytical methods. From the analysed cultivars the Ekotišnovský, Fruchtal, and Ruzyňský cultivars were evaluated as best in terms of the evaluated parameters and they can be recommended for the breeding programme of cornelian cherry fruit in the Czech Republic.

This work was supported by the National Agency for Agriculture Research, grants No. QH82232 and QI111A141.

\section{References}

Aslantas, R., Pirlak, R. \& Güleryüz, M. (2007): The nutritional value of wild fruits from the North Eastern Anatolia region of Turkey. Asian J. Chem., 19, 3072-3078.

Bijelic, S.M., Gološin, B.R., Ninic Todorovic, J.I., Cerovic, S.B. \& Popovic, B.M. (2011): Physicochemical fruit characteristics of cornelian cherry (Cornus mas L.) genotypes from Serbia. Hort. Sci., 46, 849-853.

Brindza, P., Brindza, J., Tóth, D., Klimenko, S.,V. \& Grigorieva, O. (2009): Biological and commercial characteristics of cornelian cherry (Cornus mas L.) population in the gemer region of Slovakia. Acta Hort., $818,85-94$

Demir, F. \& Kalyoncu, I.H. (2003): Some nutritional, pomological and physical properties of cornelian cherry (Cornus mas L.). J. Fd Eng., 60, 335-341.

Driskell, J.A. (2009): Upper safe limits of intake for adults: Vitamins and minerals. NebGuide G1981, UNL Extension, Nebraska. 4 pages

Güleryüz, M., Bolat, I. \& Pirlak, L. (1998): Selection of table cornelian cherry (Cornus mas L.) types in Coruh Valley. Tr. J. Agric. Forest., 22, 357-364.

Hashempour, A., Ghazvini, R.F., Bakhshi, D., Ghasemnezhad, M., Sharafti, M. \& Ahmadian, H. (2010): Ascorbic acid, anthocyanins, and phenolic contents and antioxidant activity of ber, azarole, raspberry and cornelian cherry genotypes growing in Iran. Hortic. Environ. Biotechnol., 51, 83-88.

Hassanpour, H., Hamidoghli, Y., Hajilo, J. \& Adlipour, M. (2011): Antioxidant capacity and phytochemical properties of cornelian cherry (Cornus mas L.) genotypes in Iran. Sci. Hortic., 129, 459-463.

Kalyoncu, I.H., Ersoy, N. \& Yilmaz, M. (2009): Physico-chemical and nutritional properties of cornelian cherry fruits (Cornus mas L.) grown in Turkey. Asian J. Chem., 21, 6555-6561.

Kratchanova, M., Denev, P., Ciz, M., Lojek, A. \& Mihailov, A. (2010): Evaluation of antioxidant activity of medicinal plants containing polyphenol compounds. Comparison of two extraction systems. Acta Biochim. Pol., 57, 229-234.

Kucharska, A.Z., Sokol-Letowska, A. \& Piorecki, N. (2011): Morfologiczna, fizykochemiczna i przeciwutleniająca charakterystyka owoców polskich odmian derenia właściwego (Cornus mas L.). (Morphological, physicochemical, and antioxidant profiles of Polish varieties of cornelian cherry fruit (Cornus mas L.).) Zywn.-Nauk Technol. Jakosc, 18, 78-89.

Maghradze, D., Abashidze, E., Bobokashvili, Z., Tchipashvili, R. \& Maghlakelidze, E. (2009): Cornelian cherry in Georgia. Acta Hortic., 818, 65-72.

Pantelidis, G.E., Vasilakakis, M., Manganaris, G.A. \& Diamantidis, Gr. (2007): Antioxidant capacity, phenol, anthocyanin and ascorbic acid contents in raspberries, blackberries, red currants, gooseberries and cornelian cherries. Fd Chem., 102, 777-783.

Paprštejn, F., Kosina, J., SedlÁk, J. \& ŘEzníček, V. (2009): Technologie pěstování dř́nu obecného Cornus mas L. (Cultivation technology of cornelian cherry Cornus mas L.) Research and Breeding Institute of Pomology Holovousy Ltd. 30 pages. 
Polovka, M. (2006): EPR spectroscopy: A tool to characterize stability and antioxidant properties of foods. $J . F d$ Nutr. Res., 45, 1-11.

Popovic, B.M., Štajner, D., KeVrešAn, S. \& Bijelic, S. (2012): Antioxidant capacity of cornelian cherry (Cornus mas L.) - comparison between permanganate reducing antioxidant capacity and other antioxidant methods. $F d$ Chem., 134, 734-741.

Rop, O., Mlcek, J., Kramarova, D. \& Jurikova, T. (2010): Selected cultivars of cornelian cherry (Cornus mas L.) as a new food source for human nutrition. Afr. J. Biotechnol., 9, 1205-1210.

Seeram, N.P., Schutzki, R., Chandra, A. \& Nair, M.G. (2002): Characterization, quantification and bioactivities of anthocyanins in Cornus species. J. Agric. Fd Chem., 50, 2519-2523.

TuraL, S. \& Koca, I. (2008): Physico-chemical and antioxidant properties of Cornelian cherry fruits (Cornus mas L.) grown in Turkey. Sci. Hortic., 116, 362-366.

Yilmaz, K.U., Ercisli, S., Zengin, Y., Sengul, M. \& KafKas, E.Y. (2009): Preliminary characterisation of Cornelian cherry (Cornus mas L.) genotypes for their physico-chemical properties. Fd Chem., 114, 408-412. 